\title{
Evaluation of Hepatic 11 -Hydroxysteroid Dehydrogenase Activity by Cortisone Acetate Test in Young Adults With Diabetes Mellitus Type 1
}

\author{
K. ŠIMŮNKOVÁ ${ }^{1,2}$, R. HAMPL ${ }^{1}$, M. HILL ${ }^{1}$, L. KŘÍŽ ${ }^{1}$, J. VRBÍKOVÁ ${ }^{1}$, \\ H. KVASNIČKOVÁ ${ }^{1}$, K. VONDRA ${ }^{1}$ \\ ${ }^{1}$ Institute of Endocrinology, Prague, Czech Republic, ${ }^{2}$ Third Department of Medicine, First Faculty \\ of Medicine, Charles University, Prague, Czech Republic
}

Received September 6, 2010

Accepted October 8, 2010

On-line November 29, 2010

\section{Summary}

Cortisone acetate test was performed in twelve young adult patients with diabetes mellitus type 1 , after dexamethasone administration to suppress endogenous cortisol production. Previous screening revealed that all of the subjects had peak cortisol responses in the range from subnormal to normal, as determined by a low-dose Synacthen test. The aim was to find out whether these patients would exhibit different conversion of cortisone to cortisol by $11 \beta$-hydroxysteroid dehydrogenase. Using multifactorial ANOVA the following significant relationships were obtained between cortisol or cortisol/cortisone ratio measured during the test and other parameters examined a) before dexamethasone suppression and b) during the test: a) Cortisol at $120^{\text {th }}$ minute negatively correlated with daily insulin dose and positively with basal aldosterone. Cortisol/cortisone ratio at $60^{\text {th }}$, $120^{\text {th }}, 180^{\text {th }}$, and $240^{\text {th }}$ minute negatively correlated with basal aldosterone/plasma renin activity ratio, urinary free cortisol/24 hours and positively with basal dehydroepindrosterone sulphate. b) Cortisol at $120^{\text {th }}$ minute negatively correlated with suppressed basal serum glycemia; cortisol/cortisone ratio during the whole test negatively correlated with supressed basal ACTH. The examination of peripheral metabolism of cortisol using cortisone acetate test in patients with diabetes mellitus type 1 showed adaptive changes of $11 \beta$-hydroxysteroid dehydrogenace activity associated with altered cortisol tissue supply.

\section{Key words}

Cortisone - Cortisol - Cortisone acetate test - Peripheral metabolism of glucocorticoids $\bullet$ Diabetes mellitus

\section{Corresponding author}

K. Šimůnková, Third Department of Medicine, First Faculty of Medicine, Charles University, U Nemocnice 1, 12821 Prague 2, Czech Republic. Fax: +420 224905 325. E-mail: ksimunkova@ endo.cz

\section{Introduction}

In our recent cross-sectional study of young adults with well controlled diabetes mellitus type 1 (DM1) we found in approximately one fourth of patients a decreased peak response of serum cortisol (F) during low-dose Synacthen test (LDST) (Šimůnková et al. 2010). The fact that no significant differences in metabolic control or daily dose of insulin in this group of low responders in LDST were present suggests that peripheral metabolism of $\mathrm{F}$ at the time of the study might compensate subnormal $F$ response. One of the possible mechanism could be changes in $11 \beta$-hydroxysteroid dehydrogenase (11 $\beta$-HSD1) activity, responsible for conversion of inactive cortisone (E) to active $F$ (Reichardt et al. 2000). Local $\mathrm{F}$ is involved in regulation of a number of metabolic processes (Tomlinson et al. 2004, Filipovic et al. 2008). In the major metabolising tissues F bioavaibility substantially influences glycoregulation; in liver it is primarily its effect on insulin action and intensity of gluconeogenesis (Reynolds et al. 2003, Putignano et al. 2004).

Therefore we focused on the follow up of $11 \beta$ HSD1 activity in DM1 patients. In agreement with other authors, the activity of $11 \beta$-HSD1, namely its liver 
Table 1. Fasting values of cortisol, ACTH and glucose in serum before (Day1) and after (Day 2) dexametasone aplication.

\begin{tabular}{lcccccc}
\hline & \multicolumn{3}{c}{ Day 1 } & & Day 2 & \\
\cline { 2 - 7 } Variables & median & $\begin{array}{c}\text { upper } \\
\text { quartile }\end{array}$ & $\begin{array}{c}\text { lower } \\
\text { quartile }\end{array}$ & median & $\begin{array}{c}\text { upper } \\
\text { quartile }\end{array}$ & $\begin{array}{c}\text { lower } \\
\text { quartile }\end{array}$ \\
\hline Cortisol (nmol/l) & 323 & 274 & 494 & 59 & 44 & 93 \\
ACTH $(\mathrm{ng} / \mathrm{l})$ & 21 & 14 & 29 & 3.7 & 3.0 & 4.2 \\
Glucose in serum (mmol/l) & 6.5 & 4.1 & 9.0 & 13.1 & 10.4 & 13.3 \\
\hline
\end{tabular}

isoenzyme, was assessed by cortisone acetate test, believed to provide sufficient information for clinical research (Andrews et al. 2002, Rask et al. 2002, Westerbacka et al. 2003, Tomlinson et al. 2004, Putignano et al. 2004, Stewart et al. 2005, Mai et al. 2007).

The aim was to find out whether various cortisol response in LDST observed in our young adult DM1 patients is associated with the changes of conversion of $\mathrm{E}$ to F. Multifactorial ANOVA was applied for evaluation of contribution of additional clinical and laboratory parameters on $11 \beta$-HSD1 activity.

\section{Subjects and Methods}

\section{Subjects}

Twelve young adults with well controlled DM1 with a different peak $\mathrm{F}$ response during LDST (range 438-760 nmol/1, normal response >500 nmol/l) were studied. There were 7 women and 5 men (range 30-42 years), duration of DM1 was $14 \pm 5.6$ years (mean \pm S.D.), DM1 onset $26 \pm 4.8$ years, body mass index (BMI) $24.2 \pm 3.2 \%$, glycosylated hemoglobin (HbA1C) $7.3 \pm 1.6 \%$, daily insulin dose (IU/kg/day) $0.6 \pm 0.16$. Their hormonal characteristics were: plasma renin activity (PRA) $0.45 \pm 0.24 \mathrm{ng} / \mathrm{ml}$, urinary free cortisol $/ 24$ hours (UFC/24h) $123 \pm 46 \mathrm{nmol} / 24$ hours, dehydroepindrosterone sulphate (DHEA-S) (women only) 2.64 $\pm 1.65 \mu \mathrm{mol} / \mathrm{l}$, aldosterone (aldo) $0.11 \pm 0.06 \mathrm{nmol} / \mathrm{l}$.

The following week after LDST the patients underwent at first dexametasone (dexa) suppression and on the following day they were subjected to cortisone acetate test. Fasting values of F, ACTH and plasma glucose levels before and after dexa suppression in DM1 are shown in Table 1.

The dosage of insulin in DM1 patients was not changed substantially during the last month before entering the study and these doses remained unchanged the day before the test as well. Patients applied the last dose of basal insulin the evening before the investigation, on the morning of the test no prandial insulin was applied. The test was performed only in the case when no hypoglycemia occurred during the day before the test.

The healthy group $(\mathrm{H})$ consisted of 6 healthy age- sex- and BMI matched subjects. Their fasting values of $\mathrm{F}$ and ACTH before and after dexa aplication (mean \pm S.D.) were: $450 \pm 26 \mathrm{nmol} / 1 / 56 \pm 53 \mathrm{nmol} / 1$, and $15 \pm 9.8$ $\mathrm{ng} / \mathrm{l} / 2.3 \pm 1.3 \mathrm{ng} / \mathrm{l}$.

$\mathrm{H}$ did not use any drugs interfering with steroid metabolism including hormonal contraceptives, psychiatric medication or glucocorticoids in any form three month before the study. Antibodies against adrenals were not detected either in patients or in healthy subject.

We provide the data from healthy subjects not as controls, but only as an illustration of normal findings.

\section{Test protocol}

On the first day (Day 1), blood was withdrawn at 8:00 after overnight fasting from the patients and $\mathrm{H}$ subjects for determination of F, E, ACTH, aldo, PRA, DHEA-S, HbA1C, and blood glucose. The urine was also collected for determination of urinary free $\mathrm{F}$ during 24 hours (UFC/24h). At 23:00 on the Day 1, they were given $1 \mathrm{mg}$ dexa orally to suppress endogenous $\mathrm{F}$ production. All the subjects reattended the Institute at 7:30 on the following morning and blood was withdrawn again at 8:00 (time 0) for determination of basal levels of F, E, ACTH and plasma glucose. They were then given cortisone acetate $(25 \mathrm{mg})$ orally (Kortison Cyba Novartis) and blood samples were collected at $30 \mathrm{~min}$ intervals using intravenous cannula, i.e. after 30th, 60th, 90th, 120th, 180th and 240th min for determination of serum F, $\mathrm{E}$ and glucose. The blood samples for PRA determination were immediately placed into iced-cooled water bath.

Thirty minutes after sample collection, blood was centrifuged at $3000 \mathrm{rpm}$ for $15 \mathrm{~min}$ and serum was 
collected into plastic tubes. Samples were frozen at $-20{ }^{\circ} \mathrm{C}$ and stored at this temperature until analyzed.

The protocol was approved by the Ethical Committee of the Institute of Endocrinology. All the subjects signed the informed consent.

\section{Methods for steroid determination}

A high performance liquid chromatography (HPLC) system (Dionex Softron, Germering, Germany) was used for separation of cortisol from cortisone and for their quantification. It consisted of a HPLC pump system P 680 equipped with automatic flow rate control, automated sample injector ASI-100, thermostated column compartment TCC-100 and photodiode array detector PDA-100 with wavelength range 190-600 nm. A speedvacuum centrifuge (HETO, Melsungen, Germany) was used for solvent evaporation. Serum cortisol and cortisone concentrations were determined by a method using high HPLC with UV/VIS detection after solvent extraction and partitioning as follows:Serum sample $(200 \mu \mathrm{l})$ was diluted with buffer $(200 \mu \mathrm{l})$ and $11 \beta$ hydroxy-4-androstene-3, 17-dione (40 ng per sample) was added as an internal standard. The samples were extracted twice with diethyl ether $(2 \mathrm{ml})$ for $1 \mathrm{~min}$ and aquous phase was frozen. The organic phase containing steroids was decanted and evaporated under a stream of nitrogen. To avoid possible column contamination from free fatty acids, the dry residue from the extract was dissolved in $80 \%$ aquous methanol $(1 \mathrm{ml}, \mathrm{v} / \mathrm{v})$ and n-hexane $(1 \mathrm{ml})$. The mixture was extracted again for 1 min. N-hexane-containing phase was removed and discarded. The residual polar phase was evaporated at $55^{\circ} \mathrm{C}$ and the dry residue was dissolved in $15 \%$ acetonitrile $(50 \mu \mathrm{l}, \mathrm{v} / \mathrm{v})$ and mixed vigorously to rinse the tube walls. The samples were then centrifuged (2000 g, $3 \mathrm{~min}, 22{ }^{\circ} \mathrm{C}$ ) and decanted solution transferred into vials.Simultaneously, blank samples and quality control samples were processed in the same way to avoid possible contamination and to determine procedural losses of individual metabolites.

\section{HPLC separation}

Standard mixtures of cortisone and cortisol in the following concentrations were used for calibration by an external standard method: cortisone $(25,50,100,250$, $500,625$ and $750 \mathrm{pg} / \mu \mathrm{l})$, cortisol $(100,250,500,750$, $1500,2250$ and $3000 \mathrm{pg} / \mu \mathrm{l})$. HPLC separation was carried out using reverse phase Macherey-Nagel EC 250/4 nucleosil 100-5 $\mathrm{C}_{18}$ column $(250 \times 4 \mathrm{~mm})$ with particle size of $5 \mu \mathrm{m}$ (Macherey-Nagel, Dueren, Germany). The following protocol was used: Elution gradient: 0.0-2.1 min constant mobile phase acetonitrilewater (15:85), 2.1-12.0 min, linear gradient from methanol-acetonitrile-water $(40: 9: 51)$ to methanolacetonitrile-water (49:11.3:39.7), 12.0-15.0 min, constant mobile phase methanol (100\%), 15.0-19.0, constant mobile phase acetonitrile-water (15:85).

The temperature in the column compartment was $35^{\circ} \mathrm{C}$ and the flow rate of the mobile phase was kept constant at $0.8 \mathrm{ml} / \mathrm{min}$. Under these conditions the retention times of authentic cortisone and cortisol standards were $12.13 \mathrm{~min}$ and $12.84 \mathrm{~min}$, respectively.

The PDA-100 detector response was recorded in UV mode at $239 \mathrm{~nm}$ for cortisone and $243 \mathrm{~nm}$ for cortisol at the appropriate retention times. Cortisone and cortisol contents were determined according to a calibration curve and the values were corrected for procedural and extraction losses according to yields of internal standard.

PRA was estimated by determination of angiotensin I using RIA kit from Immunotech (Marseille, France, Czech Division, Prague, Czech Republic). The detection limit for PRA was $0.1 \mathrm{ng} / \mathrm{ml}$. Intra-assay and inter-assay c.v. were 10.4 and $10.5 \%$, physiological range $0.50-1.90 \mathrm{ng} / \mathrm{ml} / \mathrm{h}$.

Plasma ACTH was determined by IRMA kit from Immunotech in keeping with the manufacturer instructions. The detection limit was $1.2 \mathrm{pg} / \mathrm{ml}$, intraassay and inter-assay c.v. were 9.1 and $9.6 \%$, physiological range 1.0-50.0 ng/l.

Serum aldo was determined by RIA kit from Immunotech after extraction into dichloromethane. Intraand inter assay c.v. were 7.8 and $8.4 \%$, physiological range (nmol/1): 0.01-0.50.

DHEA-S was determined by RIA kit from Immunotech. Intra- and inter- assay c.v. were 4.2 and $7.2 \%$, physiological range $(\mu \mathrm{mol} / 1)$ : Females $30-40$ years 1.80-9.70, 40-50 years 0.66-7.20.

UFC (free urinary cortisol) was determined by RIA kit from Orion Diagnostica (Finland). Intra-assay and inter-assay c.v. were 3.8 and $4.4 \%$, physiological range $38-208 \mathrm{nmol} / 24$ hours.

\section{Methods for determination of metabolic parameters}

Plasma glucose was measured by glucosooxidase methods on Glucose analyser; Beckman, Fullerton, CA, physiological range 3.9-5.5 mmol/1.

HbA1C was determined by imunochemical methods using quantitative immunoturbidimetry 
standardized by IFCC (Roche Diagnostics GmbH, Mannheim, Germany) on Integra 400 analyser (Roche Diagnostics GmbH, Mannheim,Germany). Intra-assay and inter-assay c.v. were 5.9 and $3.8 \%$, physiological range below $4.5 \%$ according IFCC.

\section{Statistics}

Repeated measures ANOVA model followed by least significant difference multiple comparisons were used for evaluation of cortisol profile on stage of the experiment and status of the subjects. The model consisted of the between-subject factor Status (controls, diabetics), subject factor and within-subject factor and Time (0, 30, 60, 90, 120, 180, $240 \mathrm{~min})$. For evaluation of Gaussian data distribution, the skewness and kurtosis z-score tests were applied. No data transformation was required. Multifactorial ANOVA: Relationships between $\mathrm{F}$, and $\mathrm{F}$ to $\mathrm{E}$ ratios and indices of relevant parameters bidirectionaly were evaluated by Ortogonal Projections to Latent Structures.

\section{Results}

Concentration of cortisol after cortisone acetate administration (Fig. 1)

After administration of cortisone acetate in DM1 and $\mathrm{H}$ in the first 60th minutes concentration of $\mathrm{F}$ in the serum increased to practically the same levels. After 60th minutes, the levels of serum $\mathrm{F}$ decreased fast down to $211 \mathrm{nmol} / 1$ (median) in 240th minute in $\mathrm{H}$, while in DM1 concentration of $\mathrm{F}$ continued to rise until the 120th minute. After 120 minutes, a slow decrease occurred even in this group (down) to $346 \mathrm{nmol} / 1$ in the 240th minute.

From the 60th minute, concentration of $F$ in both groups was significantly different. During the whole test, levels of F remained higher in DM1 with significance $\mathrm{p}<0.05$.

\section{Multifactorial ANOVA}

Values of $\mathrm{F}$ and $\mathrm{F} / \mathrm{E}$ ratios obtained during cortisone acetate test were analyzed by multifactorial ANOVA against:

1. peak $F$ response in serum from previous LDST;

2. fasting non-supressed values of $\mathrm{ACTH}, \mathrm{F}$, DHEA-S in women, PRA, aldo, aldo/PRA, glucose, $\mathrm{IU} / \mathrm{kg} / 24$ hours, UFC/24 hours in serum from Day 1 (measured before suppression by dexa);

3. fasting suppressed values F, E, ACTH and glucose in serum from Day 2 (measured after suppression by dexa during the test).

The results of the analysis are shown in Table 2 and 3. The following significant relationships were obtained:

Ad 1) no significant relations were found.

Ad 2) Cortisol at $120^{\text {th }}$ minute negatively correlated with daily insulin dose and positively with basal aldosterone. Cortisol/cortisone ratio at $60^{\text {th }}, 120^{\text {th }}$, $180^{\text {th }}$, and $240^{\text {th }}$ minute negatively correlated with basal aldosterone/plasma renin activity ratio, urinary free cortisol/24 hours and positively with basal dehydroepindrosterone sulphate.

Ad 3) Cortisol at $120^{\text {th }}$ minute negatively correlated with suppressed basal serum glycemia; cortisol/cortisone ratio during the whole test negatively correlated with suppressed basal ACTH.

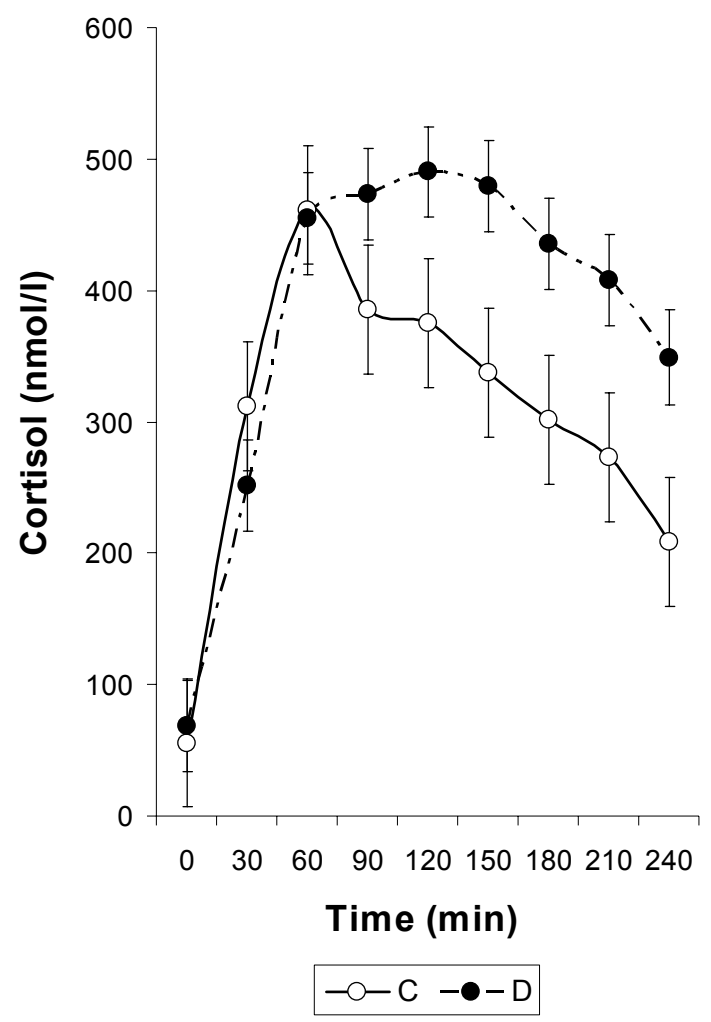

Fig. 1. Concentration of serum cortisol during cortisone acetate test. The empty circles and filled circles symbolize the means for individual stages of the test for diabetics (filled circles) and healthy subjects (empty circles), respectively. The error bars symbolize $95 \%$ confidence intervals for the means as computed using least significant difference multiple comparisons. The groups with non-overlapping $95 \%$ confidence intervals are statistically significant $(p<0.05)$. The significances of the factors $(A, B, C)$ and between-factor interaction $A \times B$ were as follows: Group $(A): F=26.64, p<0.0001$; Time $(B): F=32.72, p<0.0001$; Subject (C): $F=8.58, p<0.0001 ; A \times B: F=3.13, p=0.0028$; F...Fisher's statistics; p...significance level. 
Table 2. Relationship between cortisol in 120th min and indices of relevant parameters as evaluated by bidirectional orthogonal projections to latent structures.

\begin{tabular}{|c|c|c|c|c|c|c|c|}
\hline Variables & 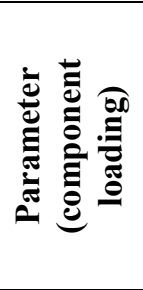 & 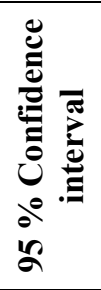 & 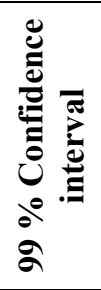 & 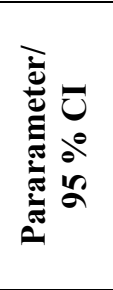 & 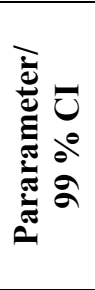 & 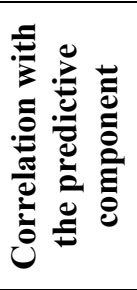 & 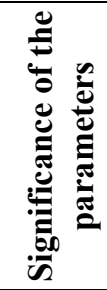 \\
\hline Cortisol, $120 \mathrm{~min}$ & 1.000 & 0.363 & 0.575 & 2.75 & 1.74 & 0.877 & $\mathrm{p}<0.01$ \\
\hline Ins $/ \mathrm{kg} /$ day & -0.542 & 0.501 & 0.792 & -1.08 & -0.68 & -0.687 & $\mathrm{p}<0.05$ \\
\hline Aldosterone & 0.559 & 0.328 & 0.518 & 4.58 & 2.89 & 0.734 & $\mathrm{p}<0.01$ \\
\hline $\begin{array}{l}\text { Basal serum glucose } \\
\text { after dexa }\end{array}$ & -0.654 & 0.194 & 0.307 & -4.08 & -2.58 & -0.825 & $\mathrm{p}<0.01$ \\
\hline $\begin{array}{l}R^{2 a)} \\
Q^{2 b)}\end{array}$ & & & & $\begin{array}{l}76.9 \% \\
65.9 \%\end{array}$ & & & \\
\hline
\end{tabular}

${ }^{a)} R^{2}$ is the percent of variation of dependent variable explained by the model; ${ }^{b} Q^{2}$ is the percent of variation of dependent variable predicted by the model according to cross validation; the model was created from all steroids and related substances investigated but only the relevant independent variables remained in the final model (for details see Statistical data analysis).

Table 3. Relationship between cortisone and indices of relevant parameters as evaluated by bidirectional orthogonal projections to latent structures.

\begin{tabular}{|c|c|c|c|c|c|c|c|}
\hline Variables & 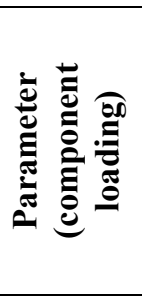 & 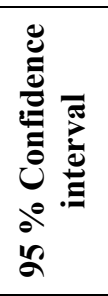 & 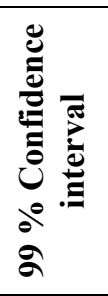 & 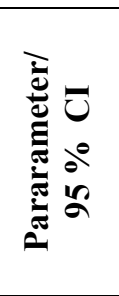 & 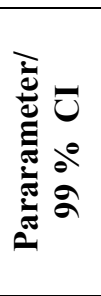 & 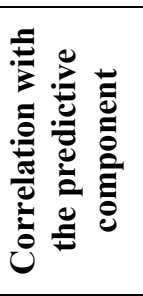 & 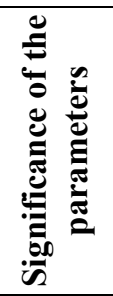 \\
\hline Cortisone, $60 \mathrm{~min}$ & 0.489 & 0.413 & 0.653 & 1.18 & 0.75 & 0.704 & $\mathrm{p}<0.05$ \\
\hline Cortisone, $120 \mathrm{~min}$ & 0.526 & 0.581 & 0.920 & 0.90 & 0.57 & 0.723 & NS \\
\hline Cortisone, $180 \mathrm{~min}$ & 0.545 & 0.420 & 0.664 & 1.30 & 0.82 & 0.777 & $\mathrm{p}<0.05$ \\
\hline Cortisone, $240 \mathrm{~min}$ & 0.433 & 0.389 & 0.616 & 1.11 & 0.70 & 0.599 & $\mathrm{p}<0.05$ \\
\hline Duration of diabetes & -0.353 & 0.465 & 0.736 & -0.76 & -0.48 & -0.601 & NS \\
\hline UFC/24 hours & 0.399 & 0.292 & 0.462 & 1.37 & 0.86 & 0.688 & $\mathrm{p}<0.05$ \\
\hline Basal ACTH & 0.457 & 0.260 & 0.412 & 1.75 & 1.11 & 0.777 & $\mathrm{p}<0.01$ \\
\hline$A C T H$, peak & 0.485 & 0.195 & 0.309 & 2.48 & 1.57 & 0.825 & $\mathrm{p}<0.01$ \\
\hline Aldosterone/PRA & 0.288 & 0.129 & 0.205 & 2.23 & 1.41 & 0.531 & $\mathrm{p}<0.01$ \\
\hline Basal ACTH after dexa & 0.489 & 0.159 & 0.251 & 3.09 & 1.95 & 0.832 & $\mathrm{p}<0.01$ \\
\hline $\begin{array}{l}R^{2 a)} \\
Q^{2 b)}\end{array}$ & & & & $\begin{array}{l}49.5 \% \\
39.5 \%\end{array}$ & & & \\
\hline
\end{tabular}

${ }^{a)} R^{2}$ is the percent of variation of dependent variable explained by the model; ${ }^{\text {b) }} \mathrm{Q}^{2}$ is the percent of variation of dependent variable predicted by the model according to cross validation; the model was created from all steroids and related substances investigated but only the relevant independent variables remained in the final model (for details see Statistical data analysis).

Correlation of area under the curve (AUC) for $F$ and $F$ to E ratio

Calculated AUC for $\mathrm{F}$ and $\mathrm{F}$ to $\mathrm{E}$ ratio have a normal Gaussian distribution and therefore were used for correlation analysis (Pearson's test) with parameters used in the ANOVA analysis.

Correlation analysis did not reveal any significant relations to AUC for $\mathrm{F}$ including relationship 
between AUC for $\mathrm{F}$ and serum peak $\mathrm{F}$ response in the LDST.

The significant correlations were found only between AUC for $\mathrm{F} / \mathrm{E}$ ratio and suppressed basal level of ACTH after dexa $(r=-0.8862, p<0.001)$.

\section{Discussion}

During the whole cortisone acetate test, levels of F remained significantly higher in DM1. When analyzing $F$ response in diabetics by multifactorial ANOVA, it appeared that the only significant relationships were found in the $120^{\text {th }} \mathrm{min}$. It is not therefore surprising that correlation analysis did not reveal any significant relations to $\mathrm{AUC}$ for $\mathrm{F}$. It indicates that with the exception of $\mathrm{F}$ value at $120^{\text {th }} \mathrm{min}$, the concentrations of serum $\mathrm{F}$ in cortisone acetate test in DM1 patients is probably influenced by other, more significant factors than by $11 \beta$-HSD1 activity. These factors are studied in the literature and include the metabolism of cortisol by $5 \alpha$ and $5 \beta$ reductases. These enzymes convert cortisol to its tetrahydro-metabolites. The factors influencing the $5 \alpha$ and $5 \beta$ reductases are still studied, the most important regulators appear to be insulin and lipids (Wake et al. 2004).

The conclusion that $F$ value at 120th min is really influenced by $11 \beta$-HSD1 activity is supported by several important relationships. At first, there is negative correlation between $\mathrm{F}$ value at 120th min and insulin dose $/ \mathrm{kg} / 24$ hours, which is in full agreement with the data

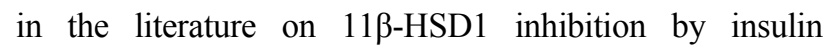
(Putignano et al. 2004). Taking into account absence of correlation of $\mathrm{F}$ value at $120^{\text {th }}$ min to $\mathrm{HbA} 1 \mathrm{C}$ and basal glycemia before dexa suppression, the relation of insulin dose to $11 \beta$-HSD1 activity appears as a factor independent on metabolic control. It should be mentioned here that all the diabetics studied were treated for a long time by an intensive insulin system basal bolus. It is known that insulin in part activates IGF-1 receptors, which also down regulate activity of 11 $\beta$-HSD1 (Moore et al. 1999, Stewart et al. 2001, Putignano et al. 2004, Agha et al. 2007). On the other hand, a negative correlation was found between $\mathrm{F}$ values at $120^{\text {th }} \mathrm{min}$ and dexa-suppressed basal glycemia. It could be explained by manifestation of an operative shorttime down regulation of $11 \beta-H S D 1$ activity, under enhanced effect of dexa on liver gluconeogenesis with consequent hyperglycemia. Down regulation of $11 \beta$-HSD1 activity could decrease intrahepatal cortisol formation and prevent hyperglycemia worsening. It may be speculated that failure of this down regulation under a long-term glucocorticoid treatment may contribute to the steroid induced diabetes mellitus, analogically to failure of $11 \beta$-HSD1 down regulation described for rise of diabetes mellitus type 2 (Putignano et al. 2004, Valsamakis et al. 2004).

A comment is needed for a lack of relation between $\mathrm{F}$ response in cortisone acetate test and the peak cortisol response at LDST. This finding resembles the results of recent study of Paisley, who found that even subnormal peak cortisol response after hypoglycemia need not mean decreased all-day F production and should not be an automatic indication for glucocorticoid replacement therapy (Paisley et al. 2009). In our group of low responders in LSDT no significant differences occurred in metabolic control or daily dose of insulin as well (Šimůnková et al. 2010).

As the most significant factors relating with the $\mathrm{F}$ to $\mathrm{E}$ ratio response during cortisone acetate test in DM1 identified by multifactorial ANOVA were the dexa supressed ACTH values, measured immediately before starting of cortisone acetate test, and the ratio of aldo to PRA together with UFC per 24 hours from the Day 1, i.e. before administration of dexa. The negative relationships of these parameters to $\mathrm{F} / \mathrm{E}$ ratio were significant for almost all the times of the cortisone acetate test, namely at $60^{\text {th }}, 120^{\text {th }}, 180^{\text {th }}$, and $240^{\text {th }} \mathrm{min}$. As for dexa supressed ACTH values, the results points to the fact that the more pronounced is the hypothalamo-pituitary-adrenal axis suppression, the more intensive conversion of cortisone to cortisol occurs and vice versa. This conclusion is supported by very tight correlations of dexa-suppressed values of ACTH to AUC for $\mathrm{F}$ to $\mathrm{E}$ ratio ( $\mathrm{r}=-0.8862)$. Moreover, additional correlations of $\mathrm{F}$ to $\mathrm{E}$ ratio with non-supressed values of aldo/PRA ratio and UFC are indicative of compensatory increased hepatal $F$ production not only under short term dexa-suppressed HPA activity, but also at the situation of long-lasting decreased adrenal functional capacity.

The lowered aldo/PRA ratio is believed to be the most sensitive parameter of adrenal function in contrast to UFC per 24 hours, which repeatedly appeared unreliable (Ten et al. 2001, Paisley et al. 2009). Despite this fact, multifactorial ANOVA has proven that decreasing UFC 124 hours before dexa administration is accompanied by increased $\mathrm{E}$ to $\mathrm{F}$ conversion and vice versa.

A positive relationship between the $\mathrm{F}$ to $\mathrm{E}$ ratio and DHEA-S level (followed in women only) may demonstrate that the increased conversion depends also 
on the sufficient DHEA-S level.

It can be concluded that the examination of peripheral metabolism of $\mathrm{F}$ assessed by cortisone acetate test in patients with DM1 showed changes, which suggest the participation of $11 \beta$-HSD1 in the mechanism of tissue compensation of cortisol supply alteration. Our data suggest that the compensation involves 1) increase of cortisone conversion to cortisol at subclinical hypocorticalism; however increasing daily dose of insulin decreases this conversion and vice versa 2) tissue protection by decreasing conversion of cortisone to cortisol in the liver after administration of exogenous glucocorticoids.

\section{Conflict of Interest}

There is no conflict of interest.

\section{Acknowledgements}

This article is dedicated to important life anniversary of prof. Luboslav Stárka. We thank the study participants and our excellent research nurses. We also thank the members of our steroid research group. The study was supported by grant NT 11277 of the Internal Grant Agency of the Ministry of Health of the Czech Republic (IGA MZCR).

\section{References}

AGHA A, MONSON JP: Modulation of glucocorticoid metabolism by the growth hormone-IGF-1 axix. Clin Endocrinol (Oxf) 66: 459-65, 2007.

ANDREWS RC, HERLIHY O, LIVINGSTONE DEW, ANDREW R, WALKER BR: Abnormal Cortisol Metabolism and Tissue Sensitivity to Cortisol in Patients with Glucose Intolerance. J Clin Endocrinol Metab 87: 5587$5593,2002$.

FIILIPOVIC D, GAVRILOVIC L, DRONJAK S, RADOJCIC MB: Liver glucocorticoid receptor and heat shock protein 70 levels exposed to different stress model. Physiol Res 57: 205-213, 2008.

MAI K, ANDRES, BOBBERT J, MASER-GLUTH TC, MOHLI M, BAHR V, PFEIFFER AF, SPRANGER J, DIEDERICH S: Rosiglitazone decreases 11 beta-hydroxysteroid dehydrogenace type 1 in subcutaneous adipose tissue. Clin Endocrinol (Oxf) 67: 419-425, 2007.

MOORE JS, MONSON JP, KALTSAS GP, PUTIGNANO P, WOOD PJ, SHEPPARD MC, BESSER GM, TAYLOR NF, STEWART PM: Modulation of 11 beta-hydroxysteroid dehydrogenase isoenzymes by growth hormone and insulin-like growth factor: in vivo and in vitro studies. J Clin Endocrinol Metab 84: 4172-4177, 1999.

PAISLEY AN, ROWLES SV, BRANDON D, TRAINER PJ: A Subnormal Peak Cortisol Response to Stimulation Testing Does Not Predict a Subnormal Cortisol Production Rate. J Clin Endocrinol Metab 94: 1757-1760, 2009.

PUTIGNANO P, PECORI GIRALDI F, CAVAGNINI F: Tissue-specific dysregulation of 11ß-hydroxysteroid dehydrogenase type 1 and pathogenesis of the metabolic syndrome. $J$ Endocrinol Invest 27: 969-974, 2004.

RASK E, WALKER BR, SODERBERG S, DAWN E, LIVINGSTONE DEW, ELIASSON M, JOHNSON O, ANDREW R, OLSSON T: Tissue-Specific Changes in Peripheral Cortisol Metabolism in Obese Women: Increased Adipose 11 beta Hydroxysteroid Dehydrogenace Type 1 Activity. J Clin Endocrinol Metab 87: 33303336, 2002.

REICHARDT MH, BRONCHE F, BAUER A, SCHULZ G: Molecular genetic analysis of glucocorticoids signaling using the Cre/ioxP systém. Biol Chem 381: 961-964, 2000.

REYNOLDS RM, WALKER BR: Human insulin resistance: the role of glucocorticoids. Diab Obes Metab 5: 5-12, 2003.

ŠIMŮNKOVÁ K, HAMPL R, HILL M, KŘÍŽ L, HRDÁ P, JANIČKOVÁ-ŽDÁRSKÁ D, ZAMRAZIL V, VRBÍKOVÁ J, VONDRA K: Adrenocortical function in young adults with diabetes mellitus type 1. J Steroid Biochem Mol Biol 122: 35-41, 2010.

STEWART PM, BOULTON A, KUMAR S, CLARK PMS, SHACKLETON CH: Cortisol Metabolism in Human Obesity: Impaired Cortisone - Cortisol Conversion in Subjects with Central Adiposity. J Clin Endocrinol Metab 84: 1022-1027, 2005. 
STEWART PM, TOOGOOD AA, TOMLINSON JW: Growth hormone, insulin-like growth factor-1 and the cortisolcortisone shuttle. Horm Res 56 (Suppl 1): 1-6, 2001.

TOMLINSON JW, WALKER EA, BUJALSKA I, DRAPER N, LAVERY GG, COOPER MS, HEWISON M, STEWART PM: 11ß-hydroxysteroid dehydrogenase type 1: a tissue-specific regulator of glucocorticoid response. Endocrine Rev 25: 831-866, 2004.

TEN S, NEW M, MACLAREN N: Clinical Review 130: Addison's Disease 2001. J Clin Endocrinol Metab 86: 29092922, 2001.

VALSAMAKIS G, ANWAR A, TOMLINSON JW, SHACKLETON CHL, MCTERNAN PG, CHETTY R, WOOD PJ, BANERJEE AK, HOLDER G, BARNETT AH, STEWART PM, KUMA S: 11ß-hydroxysteroid dehydrogenase type 1 in lean and obese males with type 2 diabetes mellitus. J Clin Endocrinol Metab 89: 4755-4761, 2004.

WAKE DJ, WALKER BR: 11 beta-hydroxysteroid dehydrogenase type 1 in obesity and the metabolic syndrome. Mol Cell Endocrinol 215: 45-54, 2004.

WESTERBACKA J, YKI-JARVINEN H, VEHKAVAARA S, HAKKINEN AM, ANDREW R, WAKE DJ, SECKL JR, WALKER BR: Body fat distribution and cortisol metabolism in healthy men: enhanced 5beta-reductase and lower cortisol/cortisone metabolite ratios in men with fatty liver. J Clin Endocrinol Metab 88: 4924-4931, 2003. 